\title{
Determination of Vitamin C Content and Mineral Elements in Fruits Samples in Karu Metropolis, North Central Nigeria
}

\author{
Stephen Inegedu Audu ${ }^{1, ~ *, ~ E f i ~ U w h e ~ J o s h u a ~}{ }^{2}$, Ibrahim Silas ${ }^{1}$, Alheri Stephen ${ }^{2}$, Augustine Sanamo ${ }^{3}$ \\ ${ }^{1}$ Department of Chemistry, Nasarawa State University, Keffi, Nigeria \\ ${ }^{2}$ National Biotechnology Development Agency, Abuja, Nigeria \\ ${ }^{3}$ Department of Public Health, Federal Ministry of Health, Abuja, Nigeria
}

Email address:

rexaudu@gmail.com (S. I. Audu)

${ }^{*}$ Corresponding author

\section{To cite this article:}

Stephen Inegedu Audu, Efi Uwhe Joshua, Ibrahim Silas, Alheri Stephen, Augustine Sanamo. Determination of Vitamin C Content and Mineral Elements in Fruits Samples in Karu Metropolis, North Central Nigeria. Science Journal of Analytical Chemistry.

Vol. 8, No. 2, 2020, pp. 72-77. doi: 10.11648/j.sjac.20200802.16

Received: February 18, 2020; Accepted: March 9, 2020; Published: June 17, 2020

\begin{abstract}
Adequate consumption of fruits, vegetables and their juices with high vitamin $\mathrm{C}$ content and antioxidant capacity result in improved health, reduced risk of chronic diseases, optimal nutrition and general well-being. This study was to determine the vitamin $\mathrm{C}$ content of fresh fruits juices extracted from Mango, Orange, Banana and Water melon and some Mineral elements content levels in the same samples. Fruits were purchased from Masaka local markets and its metropolis in Karu, Nasarawa State. Titration method was employed to determine the vitamin C content of test sample juices, Atomic Absorption Spectrophotometric method as described by AOAC was used for the elemental analysis. Results showed that the amount of vitamin $\mathrm{C}$ in the sample was Orange $>$ Mango $>$ Water melon $>$ Banana. The mineral contents determined include: Potassium, Calcium, Sodium, Iron and Magnesium. It was observed from the result obtained that the fruits showed varying degree of concentrations of the mineral elements analyzed using the Atomic Absorption Spectrophotometer. Orange was found to contain the following levels of minerals in the descending order: Potassium $374.2 \mathrm{Mg} / \mathrm{Kg}$ followed by Magnesium $29.30 \mathrm{Mg} / \mathrm{Kg}$ followed by Calcium $12.89 \mathrm{Mg} / \mathrm{Kg}$, Sodium $11.45 \mathrm{Mg} / \mathrm{Kg}$, and Iron $4.76 \mathrm{Mg} / \mathrm{Kg}$. Watermelon was found to contain Sodium $7.09 \mathrm{Mg} / \mathrm{Kg}$, Magnesium $7.97 \mathrm{Mg} / \mathrm{Kg}$, Calcium $8.39 \mathrm{Mg} / \mathrm{Kg}$ Iron $3.08 \mathrm{Mg} / \mathrm{Kg}$ and Potassium $-2.63 \mathrm{Mg} / \mathrm{Kg}$ in the descending order. Banana's levels of minerals stood as Potassium $438.10 \mathrm{Mg} / \mathrm{Kg}$ a value even higher than that of orange which was followed by Magnesium $47.40 \mathrm{Mg} / \mathrm{Kg}$, Sodium $16.35 \mathrm{Mg} / \mathrm{Kg}$, Iron $7.69 \mathrm{Mg} / \mathrm{Kg}$, and Calcium- $18.20 \mathrm{Mg} / \mathrm{Kg}$ in the descending order. Analysis of variance ANOVA $(\mathrm{P}<0.05)$ reveals a statistically significance difference among the fruit samples studied. All the fruits samples were found to be within the international standards and consumers of these fruits can use them as good supplements as the case may be depending on their daily requirements.
\end{abstract}

Keywords: Vitamin C, Mineral Elements, Antioxidant

\section{Introduction}

Vitamin C, also known as ascorbic acid and L-ascorbic acid, is a vitamin found in various foods and sold as a dietary supplement [1]. It is used to prevent and treat scurvy. It is also an essential nutrient involved in the repair of tissue and the enzymatic production of certain neurotransmitters. It is required for the functioning of several enzymes and is important for immune system function [18]. It also functions as antioxidants. Vitamin C was discovered in 1912, isolated in 1928 , and in 1933 was the first vitamin to be chemically produced [16]. It is on the World Health Organization Model List of Essential Medicines, which lists the most effective and safe medicines needed in a health system [17]. Vitamin $\mathrm{C}$ is available as an inexpensive generic and over-the-counter medication [19]. Foods containing vitamin C include citrus fruits, kiwifruit, broccoli, Brussels sprouts, raw bell peppers, and strawberries [18]. Prolonged storage or cooking may reduce vitamin $\mathrm{C}$ content in foods [18].

Vitamin $\mathrm{C}$ is an essential nutrient for certain animals including humans. The term vitamin $\mathrm{C}$ encompasses several 
vitamers that have vitamin $\mathrm{C}$ activity in animals. Ascorbate salts such as sodium ascorbate and calcium ascorbate are used in some dietary supplements. These release ascorbate upon digestion. Ascorbate and ascorbic acid are both naturally present in the body, since the forms interconvert according to $\mathrm{pH}$. Oxidized forms of the molecule such as dehydroascorbic acid are converted back to ascorbic acid by reducing agents [5].

Vitamin $\mathrm{C}$ functions as a cofactor in many enzymatic reactions in animals (and humans) that mediate a variety of essential biological functions, including wound healing and collagen synthesis. In humans, vitamin $\mathrm{C}$ deficiency leads to impaired collagen synthesis, contributing to the more severe symptoms of scurvy [5]. Another biochemical role of vitamin $\mathrm{C}$ is to act as an antioxidant (a reducing agent) by donating electrons to various enzymatic and non-enzymatic reactions [6]. Doing so converts vitamin $\mathrm{C}$ to an oxidized state - either as semi dehydroascorbic acid or dehydroascorbic acid. These compounds can be restored to a reduced state by glutathione and NADPH-dependent enzymatic mechanisms [10, 12, 8]. In plants, vitamin $\mathrm{C}$ is a substrate for ascorbate peroxidase. This enzyme utilizes ascorbate to neutralize toxic hydrogen peroxide $\left(\mathrm{H}_{2} \mathrm{O}_{2}\right)$ by converting it to water $\left(\mathrm{H}_{2} \mathrm{O}\right)[2,11]$

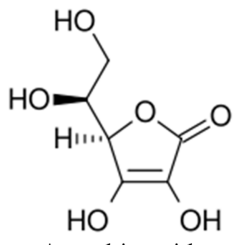

Ascorbic acid

(Reduced form)

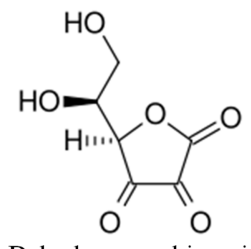

Dehydro-ascorbic acid (Oxidizedform)
Figure 1. The structure of Ascorbic Acid and Dehydro-ascorbic Acid.

While plant foods are generally a good source of vitamin C, the amount in foods of plant origin depends on the variety of the plant, soil condition, climate where it grew, length of time since it was picked, storage conditions, and method of preparation [7].

\section{Materials and Methods}

Materials include Ascorbic acid, soluble starch, 5g potassium iodide $(\mathrm{KI}), 0.28 \mathrm{~g}$ potassium iodate $\left(\mathrm{KIO}_{3}\right)$, Orange, Banana, Pineapple, and three selected commercial fruit juices. Also, other materials include $250 \mathrm{~cm}^{3}$, kitchen knife, measuring cylinder, Thermo scientific iCE 3000 series AAS and all reagents and chemicals used in this experiment were analytical grade.

\subsection{Sample Collection}

Orange, Watermelon, Banana and Mango fruits were purchased from Masaka market in Karu Local Government area of Nasarawa state Nigeria.

\subsection{Sample Preparation}

All the fruits juices were collected by blending $100 \mathrm{~g}$ sample with $50 \mathrm{ml}$ of distilled water and strain then filtered with muslin cloth and finally made to $100 \mathrm{ml}$ volumetric flask this was done after the fruits were washed with tap water and then with distilled water.

\subsection{Preparation to iodine solution}

$0.5 \mathrm{~g}$ soluble starch was added to 50 near-boiling distilled water and mixed well and allows tocool before use.

\subsection{Preparation of Iodine Solution}

$5.00 \mathrm{~g}$ potassium iodide $(\mathrm{KI})$ and $0.268 \mathrm{~g}$ potassium iodate $\left(\mathrm{KIO}_{3}\right)$ were dissolved in $200 \mathrm{ml}$ of distilled water then $30 \mathrm{M}$ of $3 \mathrm{M}$ of sulfuric acid was then added and poured into a $500 \mathrm{ml}$ graduated cylinder and diluted to a final volume of $500 \mathrm{ml}$ with distilled water then mixed well and finally transferred to a $600 \mathrm{ml}$ beaker as stock reagent.

\subsection{Preparation of Vitamin C Standard Solution}

$0.25 \mathrm{~g}$ vitamin $\mathrm{C}$ (ascorbic acid) tablet was dissolved in 100 $\mathrm{ml}$ distilled water and dilute to $250 \mathrm{ml}$ with distilled water in a volumetric flask.

\subsection{Standardizing Solutions}

$25.00 \mathrm{ml}$ of vitamin C standard solution was added to a 125 $\mathrm{ml}$ Erlenmeyer flask and 10 drops of $1 \%$ starch solution. The buret was rinsed with a small volume of the iodine solution and then filled and record as the initial volume.

The solution was titrated until the endpoint was reached observed by the emergence of the first sign of blue color that persists after 20 seconds of swirling the solution.

\subsection{Sample Digestion}

$1 \mathrm{~g}$ each of the samples was weight using a weighing balance and transferred to a test-tube, $20 \mathrm{ml}$ of concentrated Nitric acid was measured using a graduated cylinder and transfer into the test-tube and the mixture was heated using heating mantle until a clear solution was obtained indicating a complete digestion or extraction of the sample content.

\subsection{Mineral Analysis}

Mineral elements ( $\mathrm{Mg}, \mathrm{Ca}, \mathrm{Na}, \mathrm{Fe}$, and $\mathrm{K}$ ) were determined using atomic Absorption spectrophotometer (AAS), with the appropriate hollow cathode lamp and wavelength of each of the metals.

\subsection{Statistical Analysis}

Data collected was subjected to one way Analysis of variance (ANOVA) to assess whether heavy metals varied significantly between location, possibilities less than 0.05 $(\mathrm{P}<0.05)$ will be considered statistically significant.

\section{Results}

The result of the Vitamin C concentrations levels from the studied fruits samples in Masaka metropolis, are presented in Table 1 and Table 2 shows the concentrations of mineral 
elements parameter values of the fruits samples.

Table 1. Results Obtained For Iodine Solution Method.

\begin{tabular}{|c|c|c|c|c|}
\hline SAMPLES & INITIAL READING & $\begin{array}{l}\text { FINAL BURETTE } \\
\text { READING }\end{array}$ & $\begin{array}{l}\text { AV. VOLUME OF ACIC } \\
\text { USED (MI) }\end{array}$ & $\begin{array}{l}\text { l-ascorbic acid } \\
(\mathrm{Mg} / \mathbf{1 0 0 g})\end{array}$ \\
\hline \multirow{3}{*}{ VITAMIN C TABLET } & 0.00 & 18.00 & \multirow{3}{*}{18.00} & \multirow{3}{*}{100.00} \\
\hline & 0.00 & 18.00 & & \\
\hline & 0.00 & 18.00 & & \\
\hline \multirow{3}{*}{ MANGO } & 0.00 & 3.10 & \multirow{3}{*}{3.11} & \multirow{3}{*}{17.30} \\
\hline & 0.00 & 3.10 & & \\
\hline & 0.00 & 3.00 & & \\
\hline \multirow{3}{*}{ BANANA } & 0.00 & 1.60 & \multirow{3}{*}{1.60} & \multirow{3}{*}{8.70} \\
\hline & 0.00 & 1.60 & & \\
\hline & 0.00 & 1.60 & & \\
\hline \multirow{3}{*}{ ORANGE } & 0.00 & 9.00 & \multirow{3}{*}{9.00} & \multirow{3}{*}{50.20} \\
\hline & 0.00 & 9.01 & & \\
\hline & 0.00 & 9.00 & & \\
\hline \multirow{3}{*}{ WATER MELON } & 0.00 & 2.20 & \multirow{3}{*}{2.23} & \multirow{3}{*}{12.40} \\
\hline & 0.00 & 2.10 & & \\
\hline & 0.00 & 2.20 & & \\
\hline
\end{tabular}

Table 2. Results Obtained For Mineral Elements Using AAS.

\begin{tabular}{lllll}
\hline Samples & Elements & N & Mean $(\mathbf{m g} / \mathbf{k g})$ & Std. Deviation \\
\hline \multirow{4}{*}{ Orange } & Pottassium & 2 & 374.2600 & $374.25 \pm 0.0035$ \\
& Sodium & 2 & 11.4500 & $11.45 \pm 0.0035$ \\
& Magnessium & 2 & 29.3000 & $29.30 \pm 0.000$ \\
& Iron & 2 & 4.8100 & $4.76 \pm 0.0106$ \\
& Calcium & 2 & 12.8900 & $12.89 \pm 0.0071$ \\
Watermelon & Pottassium & 2 & -2.6340 & $-2.63 \pm 0.0035$ \\
& Sodium & 2 & 9.3700 & $7.09 \pm 0.0035$ \\
& Magnessium & 2 & 7.9700 & $7.97 \pm 0.000$ \\
& Iron & 2 & 3.1000 & $3.08 \pm 0.0071$ \\
Banana & Calcium & 2 & 7.6400 & $8.39 \pm 0.0106$ \\
& Pottassium & 2 & 438.1000 & $438.10 \pm 0.000$ \\
& Sodium & 2 & 18.7300 & $16.35 \pm 0.0106$ \\
& Magnessium & 2 & 49.4000 & $47.40 \pm 0.0035$ \\
Mango & Iron & 2 & 7.6900 & $7.69 \pm 0.0071$ \\
& Calcium & 2 & -18.2000 & $-18.20 \pm 0.0035$ \\
& Pottassium & 2 & 367.7900 & $367.79 \pm 0.0106$ \\
& Sodium & 2 & 2.1900 & $2.18 \pm 0.0071$ \\
& Magnessium & 2 & 38.7700 & $38.77 \pm 0.0035$ \\
& Iron & 2 & 4.2600 & $4.26 \pm 0.0106$ \\
\end{tabular}

Concentration of Mineral Elements in Fruits Samples

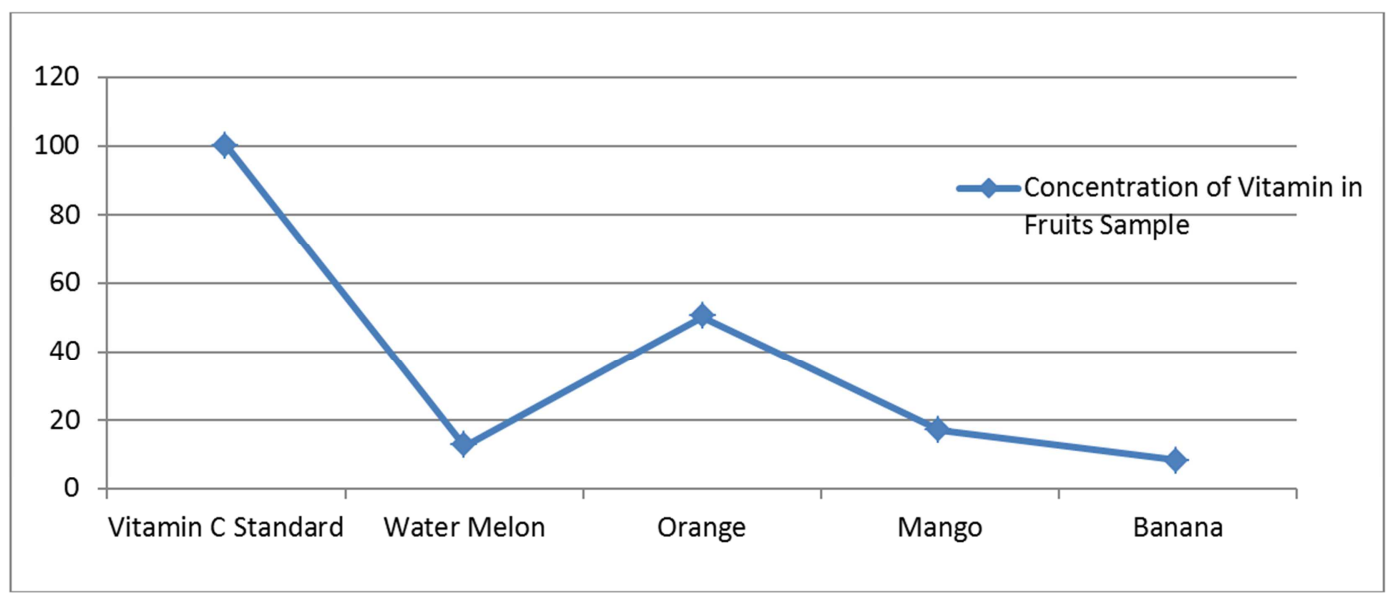

Figure 2. A Graph of Concentration against Fruits Samples for Vitamin C. 


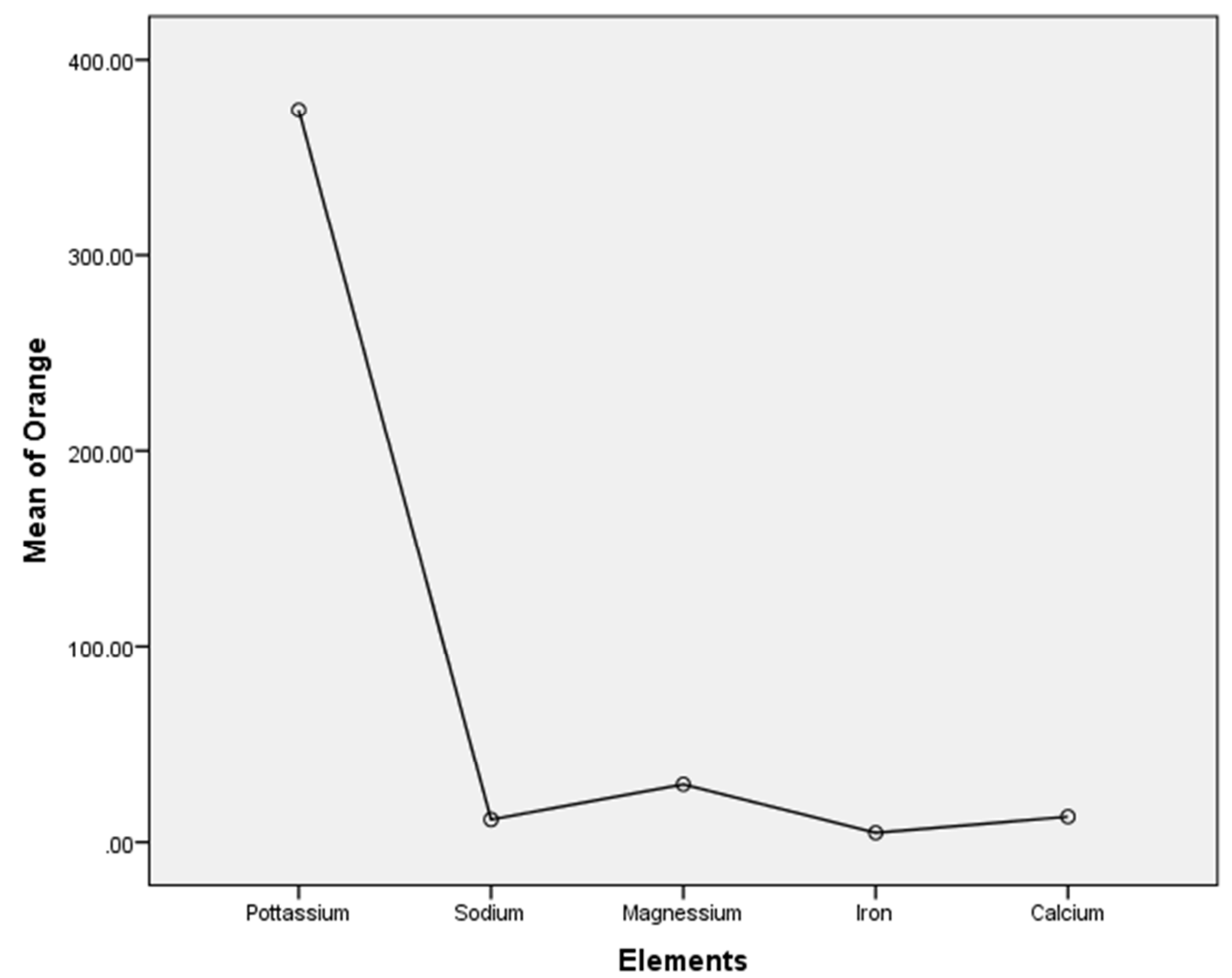

Figure 3. A Graph of Mineral Elements Concentrations Orange.

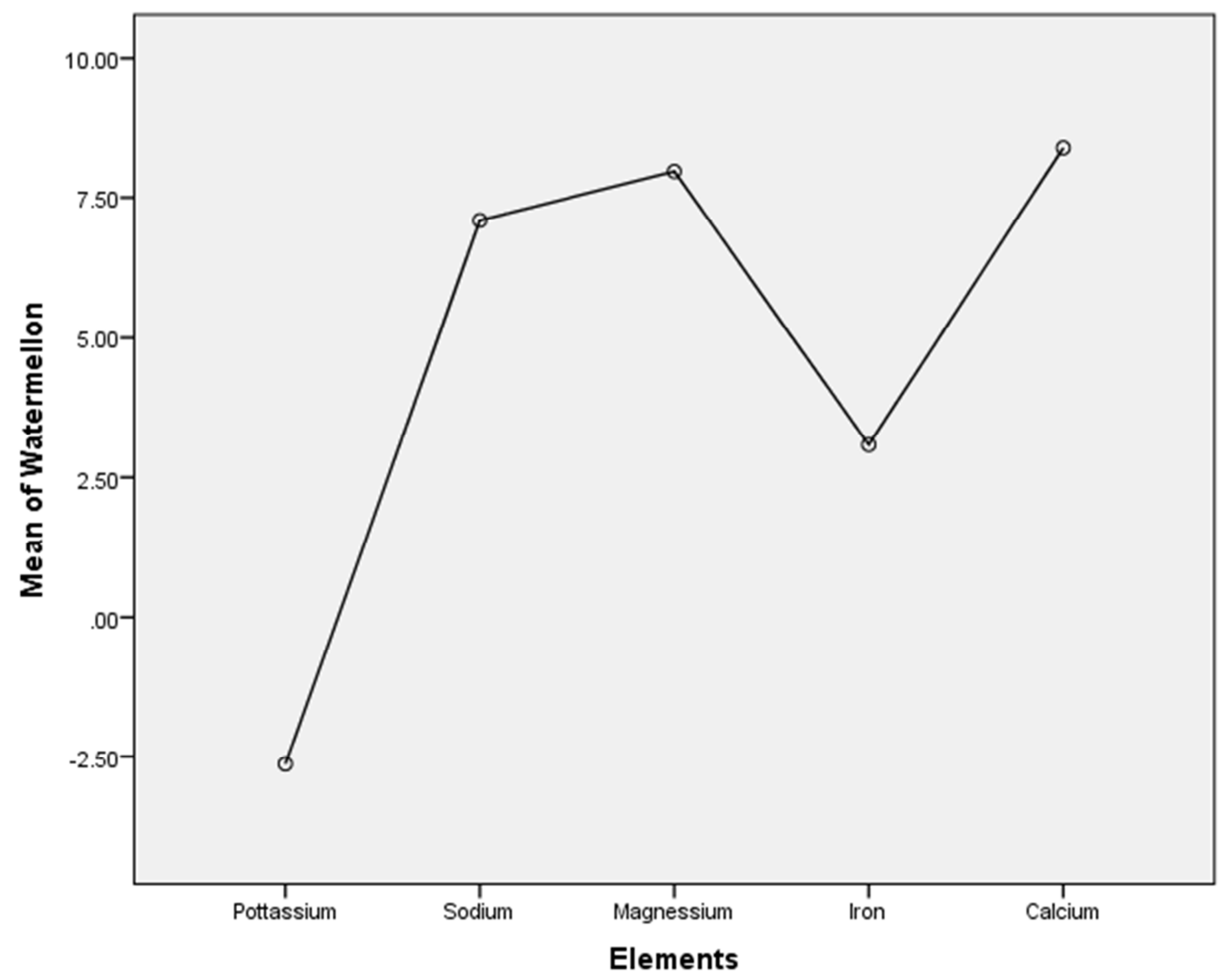

Figure 4. A Graph of Mineral Elements Concentrations in Water Melon. 

Samples in Karu Metropolis, North Central Nigeria

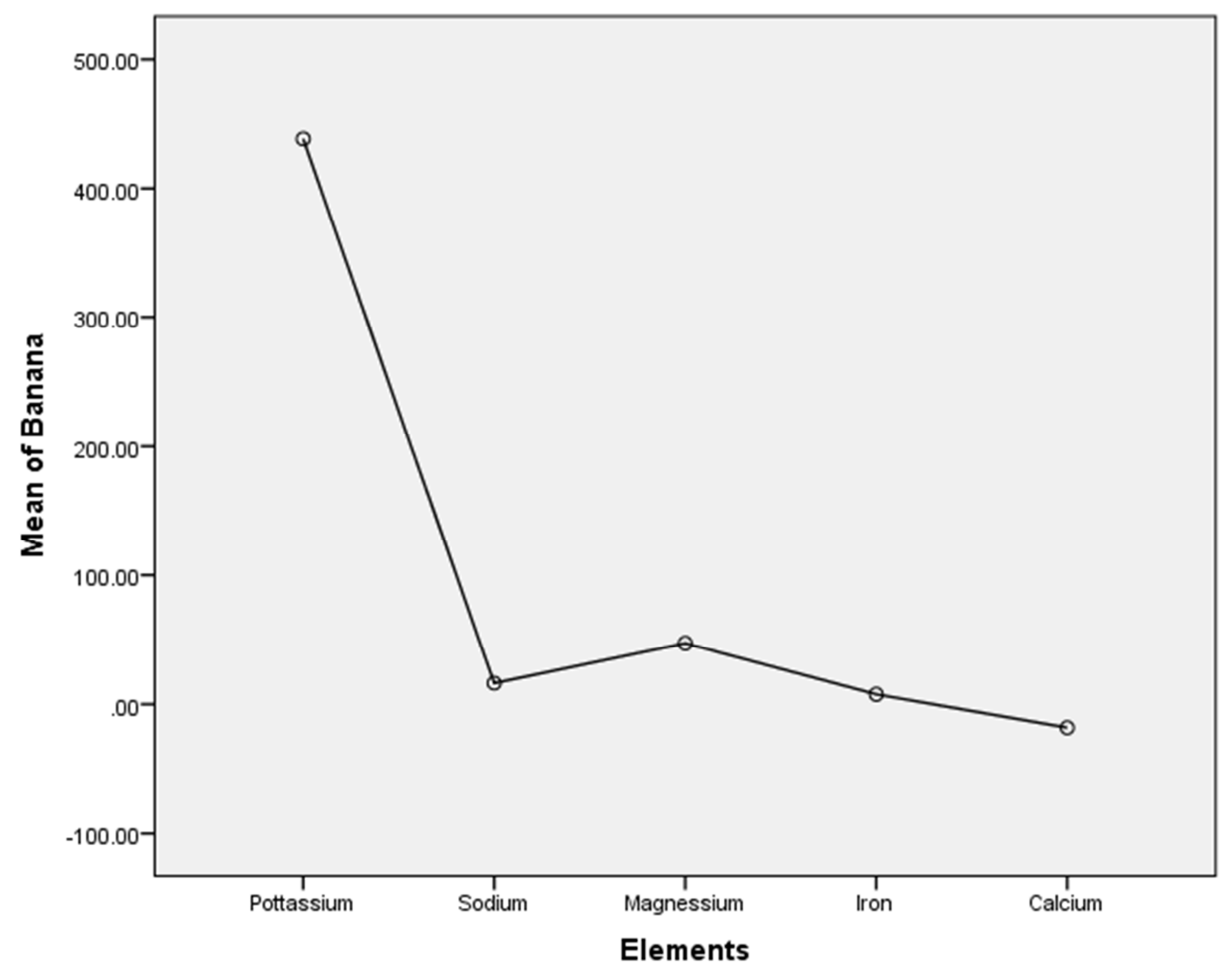

Figure 5. A Graph of Mineral Elements Concentrations in Banana.

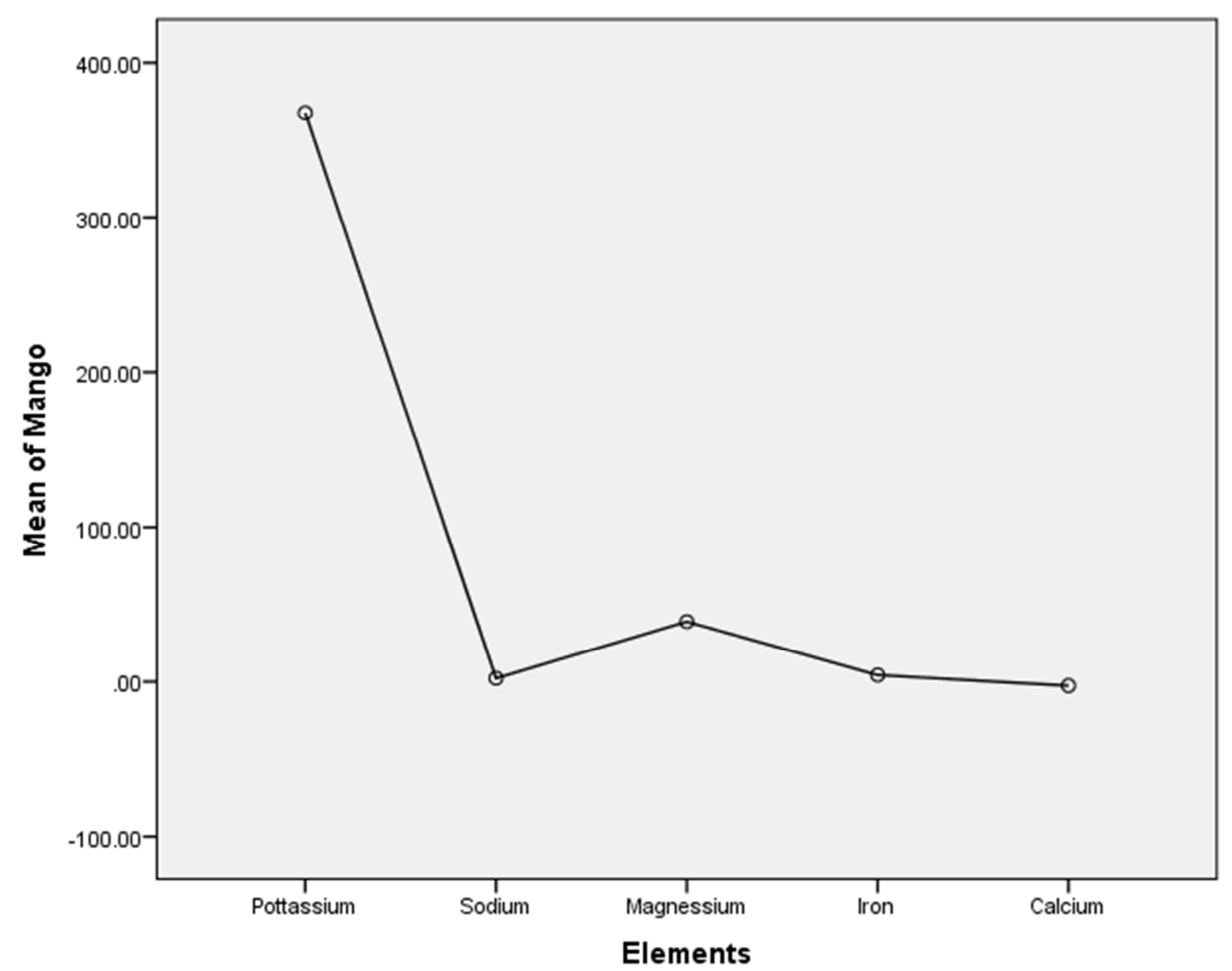

Figure 6. A Graph of Mineral Elements Concentrations in Mango. 


\section{Discussion}

Vitamin C concentrations of the fruits samples analyzed indicates that Orange has the highest with $50.20 \mathrm{Mg} / 100 \mathrm{~g}$, followed by Mango with $17.3050 .20 \mathrm{Mg} / 100 \mathrm{~g}$, Watermelon $12.4050 .20 \mathrm{Mg} / 100 \mathrm{~g}$ and Banana having the least value of $8.750 .20 \mathrm{Mg} / 100 \mathrm{~g}$. concentration of mango was found to be higher and that of orange lower compere to that obtained by [1], but higher in both cases as reported by [9] Watermelon was found to have a higher concentration when compare to the report of (3) and that of Banana a little lower than the report obtain from [18].

Some of the mineral contents determined were Sodium $(\mathrm{Na})$, Magnesium (Mg), Potassium (k), Calcium (Ca) and Manganese (Mn). As shown in Table 2, the concentrations of mineral elements determined are as follows:

Orange was found to contain (Potassium. $2>$ Magnesium $>$ $29.30>$ Calcium12.89 $>$ Sodium $>11.45>$ Iron 4.76) $\mathrm{Mg} / \mathrm{Kg}$. Watermelon was found to contain (Sodium7.09 $<$ Magnesium $7.97<$ Calcium $<8.39<$ Iron $3.08<$ Potassium $-2.63) \mathrm{Mg} / \mathrm{Kg}$ in the descending order.

Banana's levels of minerals stood as follows: (Potassium $438.10>$ Magnesium $47.40>$ Sodium $16.35>$ Iron $7.69>$ Calcium-18.20) $\mathrm{Mg} / \mathrm{Kg}$.

Mango was found to contain (Magnesium $38.77>$ Potassium $367.79>$ Iron 4.26 $>$ Sodium 2.18 $>$ Calcium-2.59) $\mathrm{Mg} / \mathrm{Kg}$.

\section{Conclusion}

The Vitamin $\mathrm{C}$ levels were found to be as follows: Orange $>$ Mango $>$ Water melon $>$ Banana. In the mineral elements determination Banana was found to contain the highest concentration of Potassium, Sodium, Magnesium and Iron except for Calcium in which Orange was found to contain the highest concentration.

\section{Acknowledgements}

Authors acknowledge all the local traders in Masaka Market and laboratory staffs.

\section{References}

[1] Amanuel Yebio, Mebrahtom G, Aman K, Gereziher G, Biruk $\mathrm{S}$ and Gomathi $\mathrm{P}$ (2015): Comparison of vitamin c content in fresh and packed juices of orange and mango. international journal of pharmacognosy vol. 2 (2): 88-92. e- issn: 23483962 .

[2] Anjum NA, Umar S, Chan M, eds. (2010). AscorbateGlutathione Pathway and Stress Tolerance in Plants. Springer. p. 324. ISBN 978-9-048-19403-2. Archived from the original on November 5, 2017. Retrieved 14 MAY 2019.

[3] Anthony Cemaluk C. Egbuonu (2015): Comparative Assessment of some Minaeral, Amino acid and Vitamin composition of Watermelon (Citrullus Lanatus) Rind and Seed. Asian journal of Biochemisty vol. 10 (5): 230-236,
2015.

[4] Daily Iron.com (2019). Iron concentration in foods.

[5] DRI (2010). Dietary Reference Intakes for Japanese 2010: Water-Soluble Vitamins Journal of Nutritional Science and Vitaminology 2013 (59): S67-S82.

[6] DRI (2017)."Vitamin C". Dietary Reference Intakes for Vitamin C, Vitamin E, Selenium, and Carotenoids. Washington, DC: The National Academies Press. 2000. pp. 95-185. ISBN 978-0-309-06935-9. Archived from the original on September 2, 2017. Retrieved 14 MAY 2019.

[7] Duarte A, Caixeirinho D, Miguel G, Sustelo V, Nunes C, Mendes M, Marreiros A (2010). "Vitamin C Content of Citrus from Conventional versus Organic Farming Systems". Acta Horticulturae. 868 (868): 389-394. doi: 10.17660/ActaHortic.2010.868.52.

[8] Gropper SS, Smith JL, Grodd JL (2005). Advanced nutrition and human metabolism. Belmont, CA: Thomson Wadsworth. pp. 260-275. ISBN 978-0-534-55986-1. Healthy eating. sfgate.com (2019).

[9] Muhammad, S. Ashiru, I. Ibrahim D., A. I. Kanoma, I. Sani, S. Garba [2014): Effect of Ripening Stage on Vitamin C Content in Selected Fruits. International Journal of Agriculture, Forestry and Fisheries. Vol. 2, No. 3, 2014, pp. 60-65.

[10] Meister A (1994)."Glutathione-ascorbic acid antioxidant system in animals". J. Biol. Chem. 269 (13): 9397-9400. PMID 8144521. Archived from the original on August 11, 2015. Retrieved 14 MAY 2019.

[11] (MIC (2014),"Vitamin C". Micronutrient Information Center, Linus Pauling Institute, Oregon State University, Corvallis, OR. January 14, 2014. Retrieved 14 MAY 2019.

[12] Michels A, Frei B (2012). "Vitamin C". In Caudill MA, Rogers M (eds.). Biochemical, Physiological, and Molecular Aspects of Human Nutrition (3 ed.). Philadelphia: Saunders. pp. 627-654. ISBN 978-1-4377-0959-9.

[13] My food.com. (2019). Mineral levels in fruits.

[14] Pemberton J (2006). "Medical experiments carried out in Sheffield on conscientious objectors to military service during the 1939-45 war". International Journal of Epidemiology. 35 (3): 556-8. doi: 10.1093/ije/dyl020. PMID 16510534.

[15] Science alert (2019). Mineral elements in fruits and vegetables, Pakistan journal of biological science.

[16] Squires VR (2011). The Role of Food, Agriculture, Forestry and Fisheries in Human Nutrition - Volume IV. EOLSS Publications. p. 121. ISBN 9781848261952.

[17] WHO (2016)."WHO Model List of Essential Medicines (19th List)". World Health Organization. April 2015. Archived (PDF) from the original on December 13, 2016, Retrieved 14 MAY 2019.

[18] Evaluation of Vitamin C and Physicochemical properties of fruits and commercial fruit juices. (2019). Unpublished M. Sc. Dissertation, Nasarawa State University, Keffi.

[19] British National Formulary (2018). BNF 76 pharmaceutical press 2018, p 1049. ISBN 9780857113382. 